\title{
Size-dependent vulnerability of juvenile bay anchovy Anchoa mitchilli to bluefish predation: Does large body size always provide a refuge?
}

\author{
Frederick S. Scharf ${ }^{1, *}$, Jeffrey A. Buckel ${ }^{2}$, Francis Juanes ${ }^{1}$ \\ ${ }^{1}$ Department of Natural Resources Conservation, University of Massachusetts, Amherst, Massachusetts 01003, USA \\ ${ }^{2}$ Department of Zoology, North Carolina State University, Center for Marine Sciences and Technology, 303 College Circle, \\ Morehead City, North Carolina 28557, USA
}

\begin{abstract}
Bay anchovy are known to be an important component of food webs in estuarine and coastal waters along the US east coast. Despite their role as a primary forage species for several toplevel predators in these systems, very little is known about their behavioral interactions with predators and the vulnerability of post-larval life stages to predation. In this study, we examined the vulnerability of juvenile bay anchovy to age- 0 bluefish predation using a size-structured laboratory design. For a range of bay anchovy and bluefish body sizes, we determined predator capture success, handling time costs, feeding rates, and prey profitabilities as functions of relative prey size. We evaluated bluefish size selection when offered different sizes of bay anchovy simultaneously and identified behavioral characteristics of prey that may contribute to disparate rates of attack. Bluefish capture success was high on small relative prey sizes $(<30 \%$ of predator size) and remained high on larger relative prey sizes ( $>50 \%$ of predator size), demonstrating that even large bay anchovy are highly susceptible to capture. Handling time and capture success relationships were combined with prey body mass to generate dome-shaped profitability curves that peaked at relative prey sizes of 0.50, which is much higher than typically observed for piscivore-prey interactions. Bluefish exhibited strong selection patterns and significantly higher attack rates on large bay anchovy. Disparate attack distributions on large and small bay anchovy appeared to be caused partly by differences in prey behavior among size groups. Our results suggest that bay anchovy may not achieve a refuge from predation with increased body size and support the importance of predation in shaping bay anchovy life history.
\end{abstract}

KEY WORDS: Bay anchovy $\cdot$ Piscivory $\cdot$ Size refuge $\cdot$ Capture success $\cdot$ Behavior

Resale or republication not permitted without written consent of the publisher

\section{INTRODUCTION}

The bay anchovy Anchoa mitchilli is one of the most abundant marine fishes in the western Atlantic and Gulf of Mexico (Hildebrand \& Schroeder 1928, Bigelow \& Schroeder 1953). Bay anchovy are small, schooling planktivores that occupy pelagic waters in habitats ranging from low salinity estuaries to the continental shelf. Along the US east coast, spawning generally occurs in the estuary and extends from approxi-

${ }^{*}$ Present address: NOAA/NMFS/NEFSC, James J. Howard Marine Laboratory, 74 Magruder Road, Highlands, New Jersey 07732, USA. E-mail: fred.scharf@noaa.gov mately May to September (Vouglitois et al. 1987, Luo \& Musick 1991, Zastrow et al. 1991) with peak spawning activity typically occurring in mid-summer that may be closely associated with peaks in food abundance (Castro \& Cowen 1991). In estuaries, large numbers of young-of-the-year bay anchovy occur during summer and early fall, and constitute the majority of estuarine population biomass (Vouglitois et al. 1987, Newberger \& Houde 1995). Relatively high abundances of multiple juvenile cohorts are usually present in east coast estuaries through October before fish migrate to continental shelf waters to overwinter.

Bay anchovy are believed to be an important trophic link in estuarine food webs (Luo \& Brandt 1993, Wang 
\& Houde 1995). Post-larval bay anchovy are preyed upon by several species of piscivorous fishes, including bluefish Pomatomus saltatrix, striped bass Morone saxatilis, weakfish Cynoscion regalis, and summer flounder Paralichthys dentatus (Poole 1964, Schaefer 1970, Manooch 1973, Merriner 1975, Friedland et al. 1988, Juanes et al. 1993, Hartman \& Brandt 1995, Juanes \& Conover 1995, Buckel et al. 1999a,b, Buckel \& McKown in press). In fact, Baird \& Ulanowicz (1989) proposed that bay anchovy may contribute up to 60 to $90 \%$ of the diets of piscivorous fishes in Chesapeake Bay. Although recent efforts have generated considerable insight as to the potential mechanisms responsible for high mortality in egg and larval stages of bay anchovy (Leak \& Houde 1987, Castro \& Cowen 1991, Cowan \& Houde 1992, 1993, Houde et al. 1994, Purcell et al. 1994, Dorsey et al. 1996, Rilling \& Houde 1999), very little is known about the processes that operate during the juvenile stage, especially with regard to the size dependence of mortality in older individuals. Generally, mortality rates for juveniles are estimated to remain high based on annual mortality rates for entire cohorts which can be as high as $95 \% \mathrm{yr}^{-1}$ (Newberger \& Houde 1995). However, because of a lack of empirical evidence for a size-based mortality relationship in older life stages, Cowan et al. (1999) used fixed size-independent rates of mortality for juveniles and adults in a bay anchovy population model in Chesapeake Bay.

Predation by age- 0 juvenile bluefish can represent a significant source of mortality for juvenile bay anchovy in estuarine and marine systems. In the estuarine portion of the Hudson River, juvenile bay anchovy were the most consistently recovered prey from the stomachs of spring-spawned age-0 bluefish during summer and early fall of 1989 to 1993 (Juanes et al. 1993, Buckel et al. 1999a). Diets of spring-spawned age-0 bluefish on the continental shelf during fall are also dominated by juvenile bay anchovy, as percent composition by weight generally ranged between 40 and $50 \%$ across shelf regions during 1994 and 1995 (Buckel et al. 1999b). Summer-spawned age-0 bluefish are even further dependent upon young bay anchovy as a source of food. In Great South Bay, New York, Juanes \& Conover (1995) reported that bay anchovy accounted for 58 to $86 \%$ by weight of summerspawned age-0 bluefish diets during 1988 and 1989. Similarly, Buckel et al. (1999b) found that juvenile bay anchovy contributed up to $90 \%$ composition by weight to diets of summer-spawned bluefish in continental shelf waters during fall.

The consistent occurrence of juvenile bay anchovy in the diets of estuarine and marine piscivores is probably due in some part to their high abundance levels relative to other forage species, which result in high rates of encounter with potential predators. However, no informa- tion exists on their susceptibility to predators once they are encountered, which may have significant influence in determining their contribution to the diets of predatory fishes. For instance, interannual variations of up to an order of magnitude in bay anchovy abundance have been demonstrated in Chesapeake Bay and Barnegat Bay estuaries (Vouglitois 1987, Newberger \& Houde 1995). Despite large interannual fluctuations in abundance that may generate considerable variability in encounter rates with predators, juvenile bay anchovy remain a consistent prey included in piscivore diets both within and across years in systems that have been studied (Manooch 1973, Friedland et al. 1988, Juanes \& Conover 1995, Buckel et al. 1999a,b). A more thorough understanding of size-structured predator-prey relations among juvenile bay anchovy and their piscivorous predators will help to determine the relative importance of bay anchovy availability (encounter rate), and/or susceptibility to attack and capture towards their overall vulnerability to predation.

Here, we evaluate the size-dependent vulnerability of juvenile bay anchovy to predation by age-0 juvenile bluefish through a series of laboratory experiments and analysis of predator diets in the field. Video recorded feeding trials are conducted across a range of anchovy and bluefish body sizes to determine predator capture success, handling time, and feeding rates as functions of relative prey size (prey length/predator length ratio). Anchovy mass ingested is combined with capture success and handling time relationships to generate size-dependent profitability curves. To determine predator size selection, we present bluefish predators with different sizes of bay anchovy simultaneously in large laboratory mesocosms and quantify size-specific patterns of prey mortality. Mesocosm experiments are recorded on video to estimate predator attack proportions on different sized anchovy and evaluate potential behavioral mechanisms of observed feeding patterns. Absolute and relative sizes of bay anchovy eaten in the field by bluefish are examined and compared to laboratory predicted vulnerabilities.

\section{MATERIALS AND METHODS}

Field collections and laboratory maintenance. Age0 bluefish (60 to $80 \mathrm{~mm}$ TL [total length] at capture) were collected during June of 1999 and 2000 in Jamaica, Little Neck, and Manhasset bays, which are estuaries in western Long Island, New York $\left(40^{\circ} 40^{\prime} \mathrm{N}\right.$, $73^{\circ} 45^{\prime} \mathrm{W}$ ). Additional bluefish were captured throughout summer months in Sandy Hook Bay located in the mid-Atlantic Bight in central New Jersey $\left(40^{\circ} 24^{\prime} \mathrm{N}\right.$, $\left.74^{\circ} 00^{\prime} \mathrm{W}\right)$. All bluefish were captured by using $30.5 \times$ $2 \mathrm{~m}$ and $61 \times 3 \mathrm{~m}$ beach seines and promptly taken 
to the James J. Howard Marine Laboratory (National Marine Fisheries Service, Northeast Fisheries Science Center) Highlands, New Jersey, USA. Fish were transported in aerated coolers (ca. 100 l) containing ambient seawater and transferred to $1500 \mathrm{l}$ circular flow-through seawater tanks ( $1.8 \mathrm{~m}$ diameter $\times 0.6 \mathrm{~m}$ depth) for acclimation of at least $1 \mathrm{wk}$ prior to use in feeding experiments. Bluefish were fed a combination of live and frozen fish prey twice daily and were maintained throughout the experimental period at ambient water temperatures (19 to $21^{\circ} \mathrm{C}$ ), salinities (22 to $27 \mathrm{ppt}$ ), and light conditions (14:10 h light:dark cycle) consistent with conditions during summer in Sandy Hook Bay.

Juvenile bay anchovy ( 25 to $45 \mathrm{~mm}$ TL at capture) were captured primarily in the Navesink River estuary immediately adjacent to Sandy Hook Bay during July to September of 1999 and 2000. Additional bay anchovy were captured along ocean beaches within $30 \mathrm{~km}$ south of Sandy Hook Bay during early fall of each yr. Both $9.1 \mathrm{~m}$ beach seines and $4.9 \mathrm{~m}$ otter trawls were used to capture juvenile bay anchovy. Seines were never retrieved to the beach, but rather were pursed in the water column after seining for 1 to $2 \mathrm{~min}$. Otter trawls were fitted with a rectangular PVC frame $(1.0 \times 0.5 \times 0.5 \mathrm{~m})$, modifying the cod end into a live box. To minimize handling stress and injury from direct contact with mesh walls, juvenile bay anchovy were retrieved from fishing gear using a plastic scoop and placed into aerated coolers or buckets (19 to 38 l) containing ambient estuarine water for transport to the laboratory.

In the laboratory, juvenile bay anchovy were acclimated over a 6 to $8 \mathrm{~h}$ period from ambient Navesink River estuary water $\left(22\right.$ to $24^{\circ} \mathrm{C}$ water temperature; 5 to $10 \mathrm{ppt}$ salinity) to ambient Sandy Hook Bay water (19 to $21^{\circ} \mathrm{C}$ water temperature; 22 to $27 \mathrm{ppt}$ salinity) and then transferred to $1500 \mathrm{l}$ circular, flow-through tanks for at least $2 \mathrm{wk}$ prior to use in feeding experiments. Bay anchovy were fed twice daily a diet of live cultured and frozen brine shrimp, and a commercial feed ( $710 \mu \mathrm{m}$ particle size) throughout the summer.

Since predation experiments required individual bay anchovy to be measured, a brief experiment was conducted prior to the start of feeding experiments to evaluate the potential effects of handling on bay anchovy behavior and survival. Multiple groups of measured and unmeasured fish of similar body size were held separately and monitored for $10 \mathrm{~d}$ following handling. Only 1 bay anchovy failed to survive (1 unmeasured fish died on Day 2) and no behavioral differences between the treatments could be detected. Fish in both treatments fed normally within 4 to $6 \mathrm{~h}$ after being transferred to experimental tanks.

Experimental design. Size-dependent capture success, handling time, and prey profitability: A total of 47 experimental feeding trials was completed during summers of 1999 and 2000 at the James J. Howard Marine Laboratory. Experiments were completed using individual fish predators randomly sampled with replacement from laboratory populations of bluefish ( $\mathrm{n}=50$ to 60 individuals per summer). If predator sampling was completely random, each individual predator would be expected to be used in 2 to 3 experimental trials feeding on bay anchovy throughout the summer. Juvenile bay anchovy used in feeding experiments were supplied from laboratory populations consisting of 1000 to 1500 individuals each summer.

Feeding trials to determine size-dependent capture success, handling times, and feeding rates were conducted in $475 \mathrm{l}$ rectangular flow-through tanks $(1.05 \times$ $0.76 \times 0.60 \mathrm{~m}$ depth) equipped with a clear, plexiglass viewing window and maintained at water depths of $0.50 \mathrm{~m}$. The bottom of each tank was covered with a thin layer $(10 \mathrm{~mm})$ of course sand. Two $150 \mathrm{~W}$ halogen bulbs positioned $1.0 \mathrm{~m}$ above each tank provided experimental lighting in addition to the overhead fluorescent lighting present in the laboratory. All feeding trials were recorded using video cameras placed approximately $1.0 \mathrm{~m}$ directly in front of each tank.

For each feeding trial, a group of 3 size-matched (10 $\mathrm{mm}$ TL range) bluefish was starved for at least $12 \mathrm{~h}$, and acclimated to experimental arenas $(475 \mathrm{l}$ glass front tanks) for 6 to $8 \mathrm{~h}$ prior to the start of the experiment. A group of 10 size-matched (5 mm TL range) juvenile bay anchovy were then added to the experimental arena and allowed to acclimate for 10 to $15 \mathrm{~min}$ inside a clear, plexiglass holding chamber before the chamber was removed and the predators had access to the prey. All feeding trials lasted for $15 \mathrm{~min}$, at which time all fish were removed and remaining prey were counted. Feeding trials were completed using a range of sizes of bluefish (90 to $180 \mathrm{~mm}$ TL), and bay anchovy ( 30 to $65 \mathrm{~mm} \mathrm{TL}$ ) that closely resembled the natural range for each species occurring in estuarine waters during summer months, allowing estimation of predation components for a wide range of relative prey sizes ( 0.20 to 0.65 prey length/predator length ratio).

Bluefish capture success and handling time were estimated from video analysis of feeding trials. Capture success was measured separately for each feeding trial as the number of successful attacks (strikes) divided by the total number of attacks. Successful attacks were those resulting in consumption of the prey. Handling time was measured for each prey consumed within a feeding trial beginning with the time of initial contact with the prey until opercular movements ceased and normal schooling behavior resumed. Within each feeding trial, handling times for each prey consumed were averaged. Bluefish feeding rates were calculated for each feeding trial as the number of prey eaten per predator per unit time (no. prey eaten $\times$ no. predators ${ }^{-1} \times \mathrm{h}^{-1}$ ). 
Linear regressions were fit to express bluefish capture success on juvenile bay anchovy as a function of relative prey size (prey length:predator length ratio). Mean handling times were linearized ( $\log _{\mathrm{e}}$ transformed) before regressions were fit to determine handling time as a function of relative prey size. Regressions were fit to linearized feeding rate data $\left(\log _{e}[y+1]\right)$. Sizedependent profitability as a function of relative prey size was calculated as prey mass ingested $\times$ predator mass $^{-1} \times$ handling time ${ }^{-1} \times$ capture success.

Bluefish size-selectivity: Feeding trials to determine size-selectivity of bluefish on bay anchovy were conducted in $1800 \mathrm{l}$ rectangular flow-through tanks $(2.4 \times$ $0.80 \times 0.80 \mathrm{~m}$ ) equipped with a plexiglass viewing window along the entire tank length. Tanks were separated into 2 chambers with an opaque plexiglass divider; 1 predator holding chamber (approximately $40 \%$ of tank volume) and 1 experimental feeding arena (approximately $60 \%$ of tank volume). The 2 chambers were connected by a door within the opaque plexiglass divider that was operated remotely to allow predators access to the feeding arena. Tank bottoms were covered with a $10 \mathrm{~mm}$ layer of coarse sand and one corner of the tank contained a patch $(0.5 \times 0.4 \mathrm{~m})$ of simulated eelgrass with a shoot density $\left(240\right.$ shoots $\left.\mathrm{m}^{-2}\right)$ within the density range observed in eelgrass patches in local estuarine waters.

Each size-selection trial involved a group of 3 sizematched (10 mm TL range) bluefish (150 to $180 \mathrm{~mm}$ TL) being offered 2 size groups (small and large, each size group had a $5 \mathrm{~mm}$ TL range) of 15 juvenile bay anchovy. Small bay anchovy sizes ranged from 35 to $47 \mathrm{~mm}$ TL and were approximately 20 to $25 \%$ of predator length, whereas large bay anchovy sizes ranged from 55 to $70 \mathrm{~mm}$ TL and were approximately 35 to $40 \%$ of predator length. The average difference in TL between small and large bay anchovy across feeding trials was $22.1 \pm 1.0 \mathrm{~mm}$, with average differences in prey length:predator length ratio of $12.5 \pm$ $0.06 \%$. Each group of bluefish was starved prior to each selective feeding trial to standardize hunger levels. For this study, feeding trials were conducted using 4 to $6 \mathrm{~h}$ starvation periods, estimated as the time required to empty 50 to $70 \%$ of the gut of juvenile bluefish at 21 to $24^{\circ} \mathrm{C}$ (Buckel \& Conover 1996).

For each feeding trial, a group of 3 bluefish was placed within the predator holding chamber for a $24 \mathrm{~h}$ acclimation period. Prey were simultaneously added to the feeding arena and allowed to disperse and acclimate for $24 \mathrm{~h}$. Bluefish were fed live prey until the designated starvation period began immediately preceding each feeding trial, at which time all remaining food was removed from the predator holding chamber. Bay anchovy prey were fed a commercial feed 1 to $2 \mathrm{~h}$ prior to each feeding trial. Active, normal feeding behavior by bay anchovy served as an indicator of health prior to the start of a feeding trial. If prey did not feed normally, the trial was postponed until normal behavior was observed. At the start of each feeding trial, the door separating the predator holding chamber and the feeding arena was lifted and bluefish had access to prey. Each feeding trial was recorded for $1.5 \mathrm{~h}$ using video cameras and two $150 \mathrm{~W}$ halogen bulbs for additional lighting. At $1.5 \mathrm{~h}$, the numbers of remaining prey of each size were estimated visually, the experimental lighting was turned off and an opaque curtain was pulled in front of the tank for the remainder of the trial to minimize disturbance.

Video recording during the initial $1.5 \mathrm{~h}$ of each feeding trial allowed determination of the proportion of predator attacks on small and large bay anchovy. Selective feeding trials lasted between 16 and $18 \mathrm{~h}$, beginning in late afternoon and ending sometime after sunrise the following day. With the exception of the initial $1.5 \mathrm{~h}$, illumination was provided only by overhead fluorescent lamps programmed on a 14:10 h light:dark cycle. Therefore, bluefish fed during both dusk and dawn crepuscular periods, times when feeding activity is generally heightened in the field (Buckel \& Conover 1997). At the end of each trial, all fish were removed, and remaining prey were counted and remeasured. A priori power analyses indicated that with alpha $(\alpha)$ set at 0.05 , at least 5 replicates were needed to detect a $15 \%$ difference in mean number consumed while achieving a power $(1-\beta)$ of 0.87 . Therefore, during summers of 1999 and 2000, a total of 10 separate feeding trials were conducted to examine bluefish size selection when feeding on juvenile bay anchovy.

Size-selective feeding trials were analyzed using an ANOVA design to test for differences in the mean number of each prey size group consumed. In addition, the mean proportion of attacks on each size group were compared to an expected proportion of attacks on each size group. The probability of an attack on a small or large bay anchovy was calculated for each individual attack based on the number of individuals of each size group remaining alive immediately prior to each attack (i.e. attacks are random). The expected proportion of attacks on small and large bay anchovy for the entire feeding trial was calculated as the mean of attack probabilities for all individual attacks. For each feeding trial, the actual and expected attack proportions on each size group were arcsine square-root transformed, and then analyzed using ANOVA.

Predator size-prey size relationships in the field: Diet composition data for bluefish collected in local estuarine waters were used to analyze predator sizeprey size relationships in the field. Sizes of bay anchovy consumed by bluefish in the lower Hudson River during 1990 to 1993 were examined. Scatterplots 
of bay anchovy size versus bluefish size were constructed and variation in minimum, mean, and maximum bay anchovy size were determined as a function of predator size using regression quantiles (Scharf et al. 1998a, Cade et al. 1999). Absolute and relative sizes of bay anchovy in bluefish diets were compared to laboratory predictions based on size-dependent predator capture success, bay anchovy profitability, and predator selective behaviors to evaluate whether laboratory derived predictions matched field observations. To assess whether morphological limitations related to gape size can provide bay anchovy with a size refuge from juvenile bluefish predators, we compared bluefish gape allometries with body depths of bay anchovy, and determined maximum bay anchovy sizes ingestible by bluefish.

\section{RESULTS}

\section{Size-dependent capture success, handling time, and prey profitability}

Capture success of age- 0 bluefish preying on juvenile bay anchovy declined linearly with increasing relative prey size (Fig. 1). Bluefish capture efficiency was as high as 70 to $80 \%$ at relative prey sizes less than 0.30

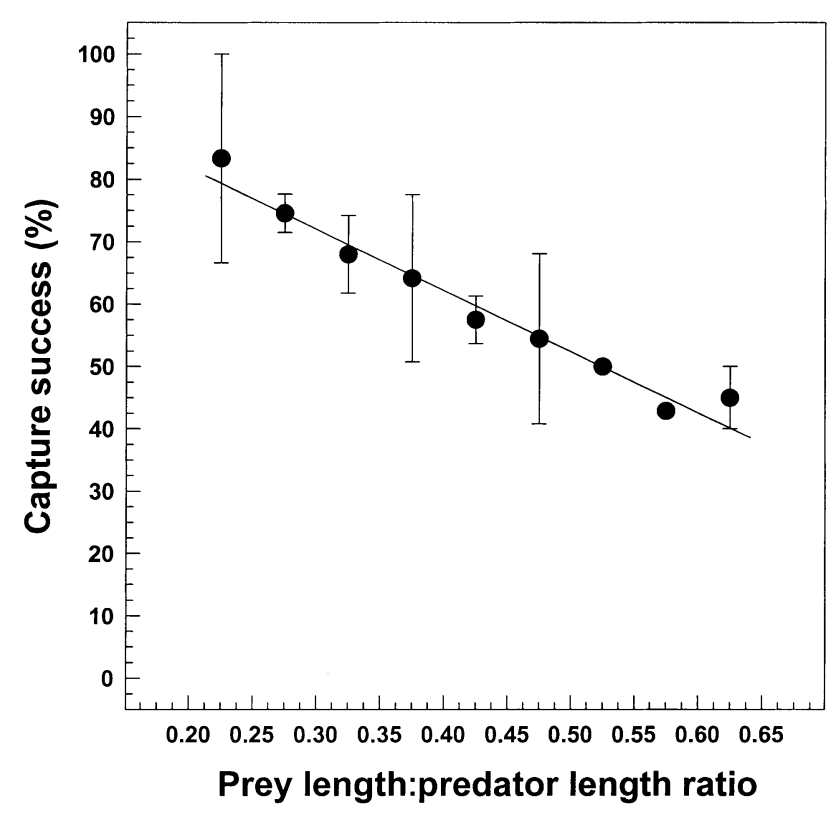

Fig. 1. Bluefish capture success on bay anchovy prey as a function of relative prey size. Capture success was calculated separately for each feeding trial as the percent of predator strikes that were successful. Means $\pm 1 \mathrm{SE}$ are presented for all trials within each 0.05 increment of relative prey size. Regression is fit to all individual trial data and equation is presented in the text

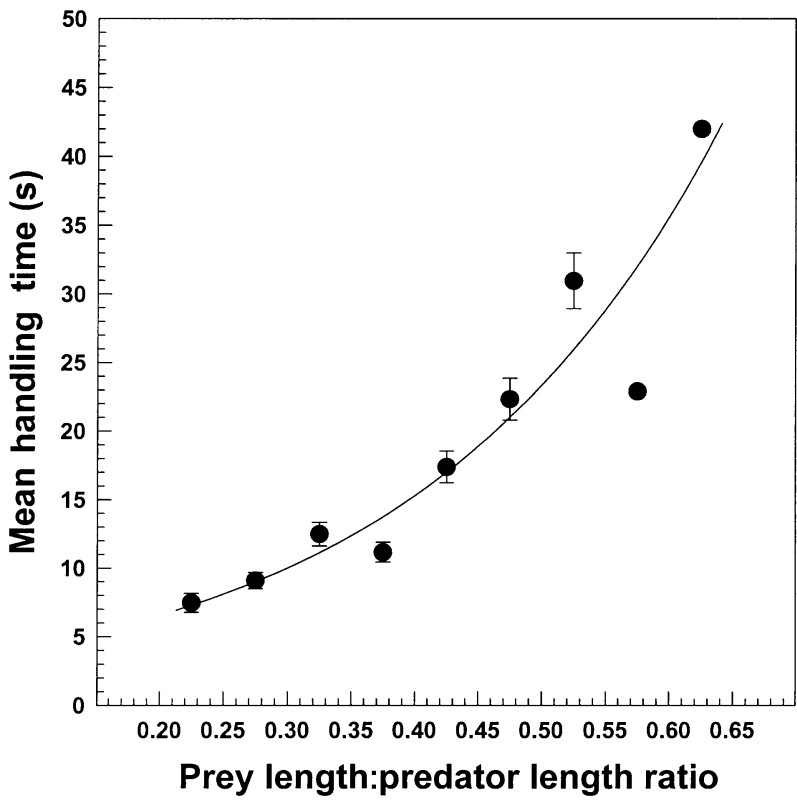

Fig. 2. Mean bluefish handling time when feeding on bay anchovy as a function of relative prey size. Means $\pm 1 \mathrm{SE}$ are presented for all trials within each 0.05 increment of relative prey size. Regression is fit to all individual trial data and equation is presented in the text

and decreased linearly to 40 to $50 \%$ at relative prey sizes greater than $0.50\left(y=1.01-0.98 x_{i} \mathrm{p}<0.0001 ; \mathrm{r}^{2}=\right.$ $0.50 ; n=47$ ). Bluefish handling time when feeding on juvenile bay anchovy increased exponentially as a function of relative prey size (Fig. 2). Handling time was less than $10 \mathrm{~s}$ for relative prey sizes under 0.30 and rose to over $30 \mathrm{~s}$ at relative prey sizes above 0.50 $\left(y=2.81 \mathrm{e}^{4.23 x} ; \mathrm{p}<0.0001 ; \mathrm{r}^{2}=0.86 ; \mathrm{n}=47\right)$. Bluefish feeding rates on juvenile bay anchovy declined exponentially with increasing relative prey size (Fig. 3). Juvenile bay anchovy were consumed at a rate of 8 to $10 \mathrm{~h}^{-1}$ at relative prey sizes less then 0.30 , and at a rate of about 3 prey $\mathrm{h}^{-1}$ at relative prey sizes greater than $0.40\left(y+1=19.87 \mathrm{e}^{-3.18 x} ; \mathrm{p}<0.0001 ; \mathrm{r}^{2}=0.51 ; \mathrm{n}=47\right)$.

Profitability of juvenile bay anchovy as a forage species for bluefish was a dome-shaped function of relative prey size (Fig. 4). Bluefish profitability rose steeply with increasing relative size of bay anchovy prey and peaked at a relative prey size near 0.50 . Relative bay anchovy sizes between 0.45 and 0.60 were about twice as profitable to bluefish predators compared to relative bay anchovy sizes around 0.30 .

\section{Bluefish size selectivity}

When offered different sizes of bay anchovy simultaneously in large aquaria, age-0 bluefish consumed significantly higher numbers of large prey $(12.0 \pm 0.8)$ 


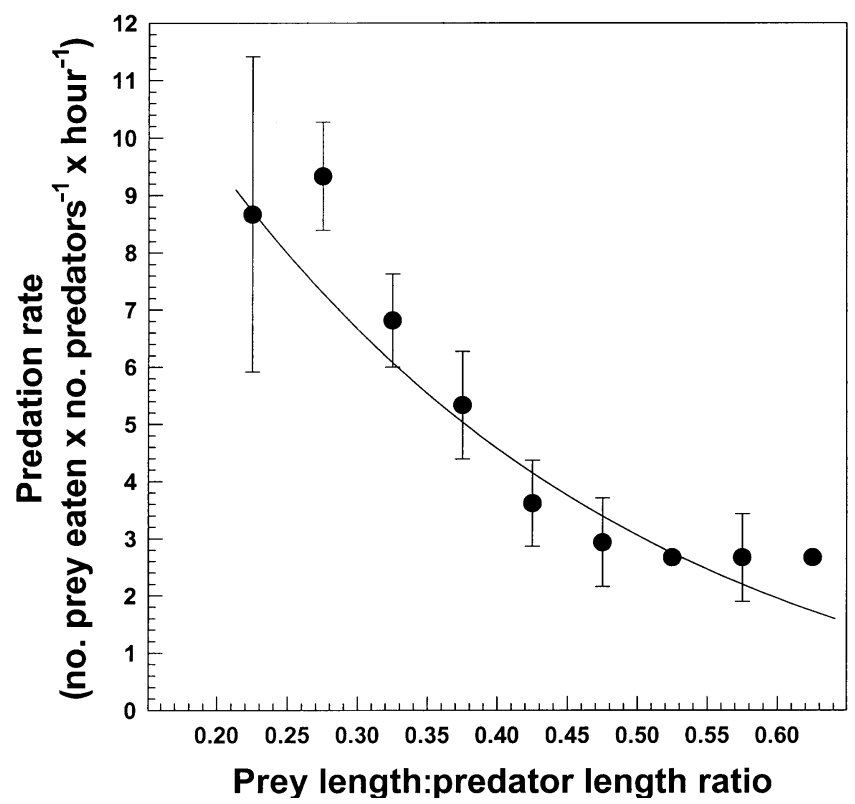

Fig. 3. Predation rate of bluefish feeding on bay anchovy as a function of relative prey size. Predation rate was calculated separately for each feeding trial as the number of prey eaten per predator per $h$. Means $\pm 1 \mathrm{SE}$ are presented for all trials within each 0.05 increment of relative prey size. Regression is fit to all individual trial data and equation is presented in the text

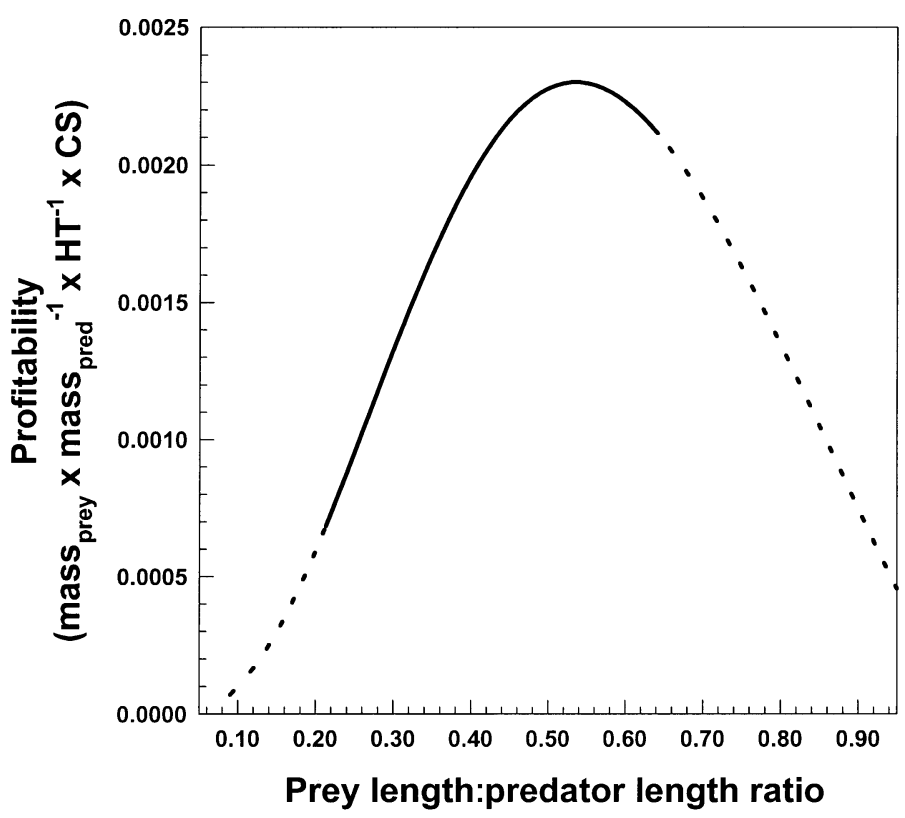

Fig. 4. Profitability of bay anchovy prey to bluefish predators as a function of relative prey size. Profitability was calculated as the relative prey mass ingested $\times$ handling time $(\mathrm{HT})^{-1} \times$ capture success (CS). The solid portion of the curve represents the range of relative prey sizes tested in this study. The dashed portions of the curve represent the extension of the predicted profitability function to the $x$-axis compared to small prey $(7.9 \pm 1.3)$ (Fig. 5a). Based on video analysis of the initial $1.5 \mathrm{~h}$ of each feeding trial, bluefish attacked significantly higher proportions of large prey than would be expected if attacks were randomly distributed among both prey size groups (observed $85.2 \%$ large:14.8\% small; expected $48.7 \%$ large:51.3\% small) (Fig. 5b).

Video observations of bay anchovy behavior made prior to the introduction of predators indicated that large and small bay anchovy grouped together in tight schools and that individuals did not stray more than 1 to 2 body lengths from adjacent individuals. Schools were located in the mid- to upper water column in the open area of the tank and anchovy did not use the eelgrass refuge. Upon introduction of bluefish at the onset of size-selection experiments, bay anchovy schools dispersed briefly before quickly reforming into a cohesive group (usually within 1 to $2 \mathrm{~min}$ ). Similar to predator free situations, large and small anchovy schooled together in the presence of bluefish, however schools were located in areas of the tank opposite to those occupied by bluefish. Bluefish generally maintained positions in mid- to upper regions of the water column near the front of the tank and did not swim into eelgrass patches, thus bay anchovy schools were located in the lower, rear areas of the tank. Contrary to predator free situations, bay anchovy made extensive use of eelgrass patches during 4 of the 10 size-selection trials.

A total of 57 bluefish attacks on bay anchovy were observed during the initial $1.5 \mathrm{~h}$ of size-selection experiments. Bluefish attacks could be broadly categorized into 1 of 3 types of attack behavior: (1) A single bluefish would approach the bay anchovy school and attack an individual prey that did not respond rapidly by fleeing, but rather remained stationary and nonreactive as the predator approached; (2) A single bluefish would approach and cause a rapid dispersal of the bay anchovy school, resulting in the isolation of several prey individuals ( 4 to 5 body lengths from the nearest neighbor), 1 of which would be subsequently attacked; Or (3) bluefish would attack an individual prey that had strayed from the school, causing it to become isolated and generally in closer proximity to predators. The majority of observed bluefish attacks $(39 ; 66.1 \%)$ fell under the third type of attack behavior, attacking individual prey that had isolated themselves by straying from the school.

The use of eelgrass patches appeared to provide a refuge for bay anchovy. The mean total number of prey eaten for the entire trial (17.8 when using grass vs 20.2 when not using grass), the mean number of prey eaten during the initial $1.5 \mathrm{~h}$ of each trial (1.3 when using grass vs 4.4 when not using grass), and the mean number of attacks observed (2.3 when using grass vs 9.2 when not using grass) were all lower during trials 
Fig. 5. Mean number eaten (a) and proportion of attacks (b) by bluefish feeding on large and small bay anchovy in size-selection experiments. ANOVA statistics are presented in each panel

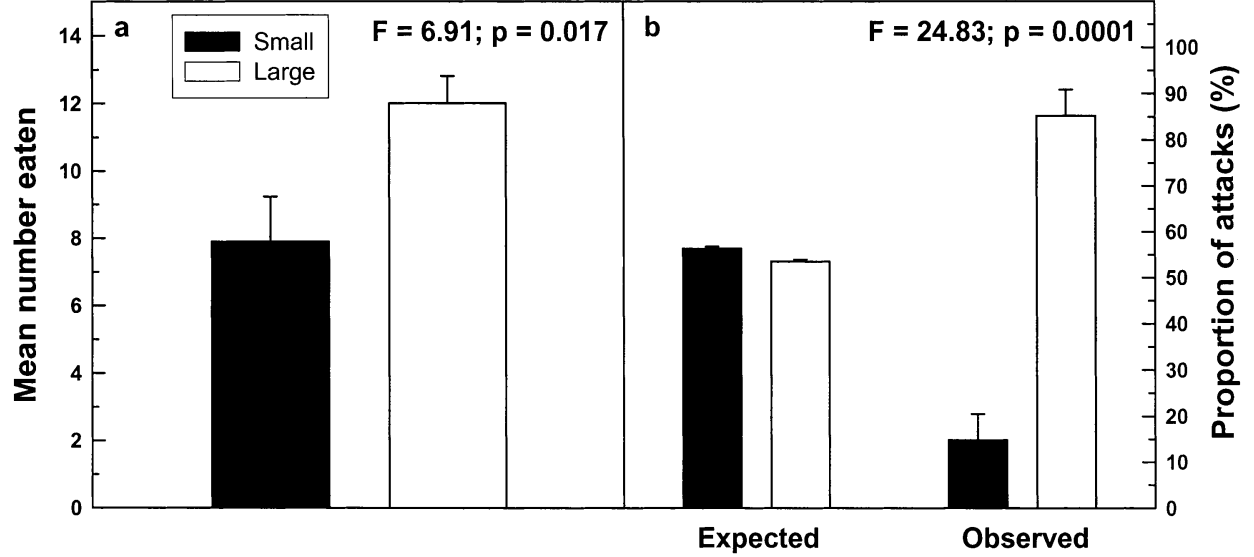

fish size. Minimum bay anchovy sizes eaten remained relatively constant with increasing bluefish size, as even the largest bluefish consumed small (15 to $20 \mathrm{~mm}$ TL) bay anchovy. Diet data indicated that bluefish are capable of eating large bay anchovy relative to their when bay anchovy made extensive use of the eelgrass, although only the difference in mean number eaten during the initial $1.5 \mathrm{~h}$ of each trial was statistically significant ( $p<0.05)$. Further, only 2 of 59 observed bluefish attacks took place within the eelgrass patches.
Table 1. Regression equations to quantify relationships for mean, maximum, and minimum sizes of bay anchovy consumed as functions of bluefish body size; bluefish gape height and throat width as functions of bluefish body size; and bay anchovy body depth as a function of body length. All regressions were highly significant $(p<0.001)$, except minimum anchovy size vs bluefish size $(\mathrm{p}<0.05) . \mathrm{TL}=$ total length. NA = not applicable, since quantile regression analyses do not generate traditional $\mathrm{r}^{2}$ values

Field diet data demonstrated that a wider range of bay anchovy sizes was consumed as bluefish size increased (Fig. 6a, Table 1). Mean bay anchovy sizes eaten increased from about 20 to $45 \mathrm{~mm}$ TL as bluefish size increased from 60 to $200 \mathrm{~mm}$ TL, whereas maximum bay anchovy sizes eaten increased more rapidly from 25 to $80 \mathrm{~mm}$ TL with increasing blue-

\begin{tabular}{|c|c|c|c|c|}
\hline Relationship & Equation & $\mathrm{n}$ & $\begin{array}{l}\text { TL range } \\
(\mathrm{mm})\end{array}$ & $\mathrm{r}^{2}$ \\
\hline Mean anchovy size & $y=0.18($ blue $\mathrm{TL})+6.95$ & 362 & $45-215$ & 0.20 \\
\hline Maximum anchovy size & $y=0.43($ blue TL $)+4.62$ & 362 & $45-215$ & NA \\
\hline Minimum anchovy size & $y=0.07($ blue $\mathrm{TL})+6.33$ & 362 & $45-215$ & NA \\
\hline Bluefish gape height ${ }^{\mathrm{a}}$ & $y=0.13($ blue TL) +2.43 & 244 & $52-240$ & 0.89 \\
\hline Bluefish throat width & $y=0.13($ blue TL) +0.84 & 21 & $90-260$ & 0.96 \\
\hline Bay anchovy depth ${ }^{\mathrm{b}}$ & $y=0.207($ anch TL $)-1.812$ & 246 & $15-80$ & 0.99 \\
\hline \multicolumn{5}{|c|}{ a From Juanes \& Conover (1995); ${ }^{b}$ From Scharf et al. (1997) } \\
\hline
\end{tabular}

Fig. 6. Predator-prey size relationship (a) for juvenile bluefish predators and bay anchovy prey based on bluefish stomach contents in the lower Hudson River estuary during summer and early fall of 1990 to 1993. Equations for regressions estimating relationships between minimum, mean, and maximum bay anchovy size and bluefish size are given in Table 1. The percent frequency of relative sizes of bay anchovy eaten by bluefish during 1990 to 1993 are presented in panel (b)

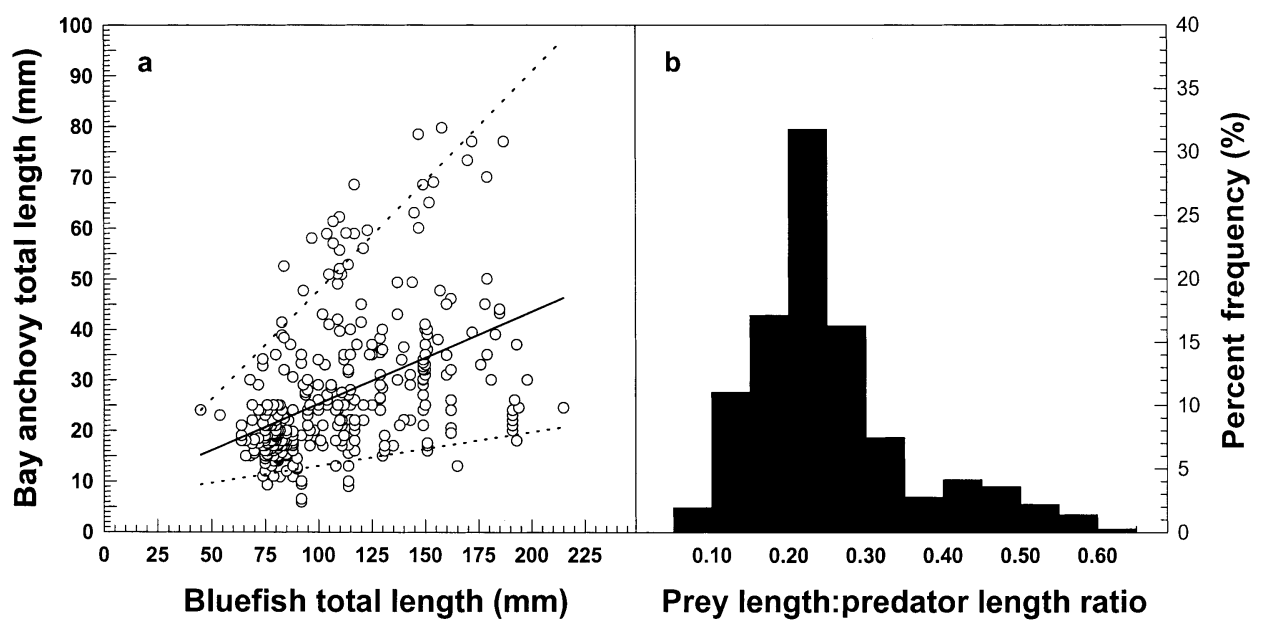


own size, as bluefish between 100 and $125 \mathrm{~mm}$ TL were often found with bay anchovy as large as $60 \mathrm{~mm}$ TL in their stomachs, and $150 \mathrm{~mm}$ TL bluefish had consumed 70 to $80 \mathrm{~mm}$ TL bay anchovy. The distribution of relative sizes of bay anchovy eaten by bluefish indicates that bay anchovy between 20 and $30 \%$ of bluefish size were eaten most frequently (Fig. 6b). However, the distribution of relative prey sizes eaten is skewed to the right with several bay anchovy greater than $40 \%$ of bluefish size being eaten. Predictions based on laboratory results differ from field patterns, predicting that larger bay anchovy (40 to $50 \%$ of bluefish size) should be more profitable compared to smaller relative prey sizes.

Measurements of bluefish gape size and bay anchovy body depth as functions of total length indicated that bluefish are morphologically capable of consuming bay anchovy up to 75 to $80 \%$ of their own body size (Fig. 7). Bay anchovy less than $40 \mathrm{~mm}$ TL are vulnerable to the entire size range of bluefish present in estuarine and marine waters during summer months, and bluefish greater than approximately $110 \mathrm{~mm}$ TL are morphologically capable of ingesting the largest sizes of bay anchovy typically present in these systems.

\section{DISCUSSION}

The outcome of interactions between predators and prey is often strongly influenced by the relative body sizes of each. Predator capture probability, handling costs, feeding rate, and overall foraging efficiency can be each estimated as a size-dependent function. For piscivorous fish predators, capture success has been identified as a critical determinant of prey selection and diet composition (Breck 1993, Juanes 1994, Juanes \& Conover 1994, Christensen 1996, Scharf et al. 1998b). Most evidence indicates that capture success in piscivores is generally low and declines rapidly for larger prey sizes (Christensen 1996, Einfalt \& Wahl 1997, Ellis \& Gibson 1997, Scharf et al. 1998b, Lundvall et al. 1999). In this study, bluefish capture success on juvenile bay anchovy was very high (70 to $80 \%$ ) for relatively small prey sizes, and declined linearly. However, the rate of decline with increasing relative prey size was slow and bluefish capture success remained high $(40$ to $50 \%$ ) for relatively large prey sizes. High bluefish capture success for a large range of bay anchovy sizes contributed to profitability curves that peaked at large relative prey sizes ( 0.50). The benefit to predators, in terms of ingested energy, increases with prey size. However, the handling costs incurred and the frequency of failed capture attempts also increase, leading to dome-shaped profitability curves that usually peak at prey sizes that are 25 to $30 \%$ of

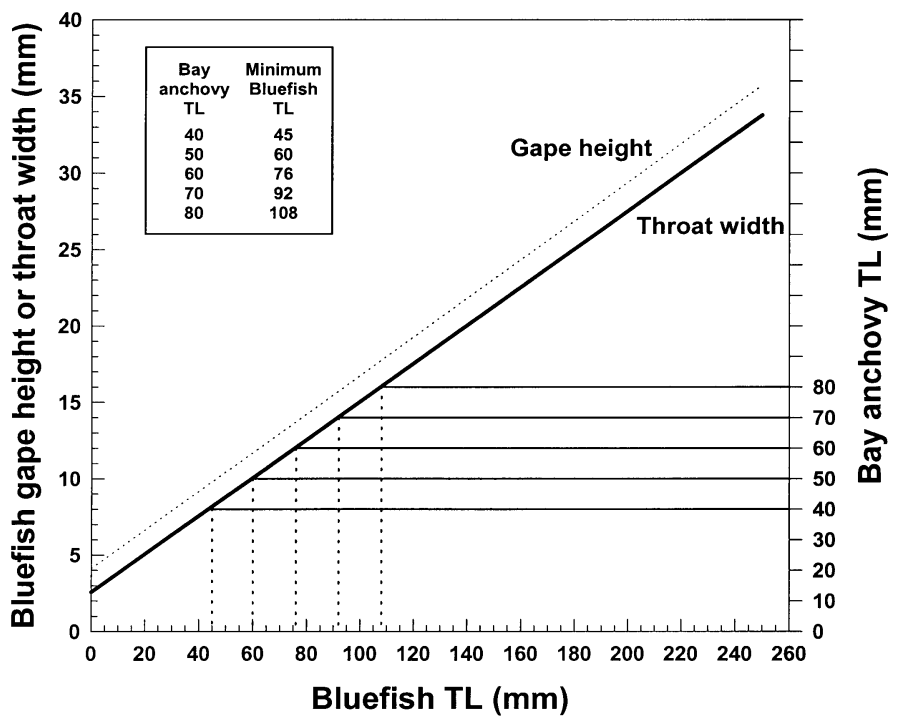

Fig. 7. Bluefish gape height and throat width, and maximum sizes of bay anchovy that bluefish are morphologically capable of ingesting as functions of bluefish size. Maximum bay anchovy total lengths (TL) are calculated from maximum body depths that are below bluefish gape sizes. Regression equations for bluefish gape allometries and the relationship between bay anchovy body depth and total length are given in Table 1. Minimum bluefish sizes required to ingest successive sizes of bay anchovy are presented in the box in the upper left

predator size (Rice et al. 1993, Ellis \& Gibson 1997, Scharf et al. 1998b). Our findings indicate that, due to high predator capture efficiency at relatively large prey sizes, bay anchovy are not typical of most piscine prey in yielding high profitability to piscivores at large prey body sizes.

Our results provide evidence that, in addition to the large abundance levels of juvenile bay anchovy typically found in coastal waters of the eastern US, their high susceptibility to capture may contribute to diet composition of marine and estuarine piscivores. For example, Buckel et al. (1999b) demonstrated that juvenile bluefish selected bay anchovy prey and avoided other prey, including butterfish and squid, based on relative prey abundances available in continental shelf waters during fall. In addition, juvenile bay anchovy have been observed to be one of the first piscine prey eaten by young striped bass when they begin piscivorous feeding (Manooch 1973, Gardinier \& Hoff 1982, Buckel \& McKown in press). Similarly, the early piscivorous stages of weakfish (age-0 juveniles) have been found to feed heavily on bay anchovy in Chesapeake Bay and North Carolina (Merriner 1975, Hartman \& Brandt 1995). In fact, the availability of easily captured bay anchovy prey may be one of the primary mechanisms enabling young predatory fishes, such as juvenile striped bass and weakfish, to shift to a piscine diet 
early during ontogeny. The ability of bluefish to feed efficiently on a wide range of bay anchovy sizes, as observed in this study, suggests that the contribution of bay anchovy to the diets of piscivorous fishes in general may be related to more than simply prey abundance.

When presented with different sizes of bay anchovy prey, bluefish strongly selected large bay anchovy individuals over small ones. This finding contradicts the general feeding patterns observed for most piscivorous fishes, in that small piscine prey are normally selected over larger prey when predators are given a choice (Hart \& Hamrin 1988, Juanes 1994, Manderson et al. 1999, Nilsson \& Brönmark 2000). Although bluefish capture success remained high on relatively large bay anchovy prey, it was lower compared to capture success on smaller relative prey sizes. Thus, the proportion of bluefish attacks on large bay anchovy would have to be exceedingly high in order to produce the ratio in the numbers eaten of large and small prey $(60: 40)$ that we observed. Indeed, bluefish attack proportions were significantly skewed towards large prey (85:15) in our size-selection experiments.

Significant differences in attack proportions between prey sizes could be interpreted as evidence for active behavioral choice by bluefish predators; however, differences in prey behavior may have contributed to the patterns of attack that we observed. Several authors have proposed that morphological and behavioral characteristics of prey contribute substantially to patterns of selective foraging by predators feeding on mobile prey (Hart \& Hamrin 1990, Sih \& Moore 1990, Juanes \& Conover 1994, Christensen 1996). Sih \& Christensen (2001) argue that optimal diet theory has not performed well in predicting the diets of foragers attacking mobile prey, and that differences in vulnerability of prey related to encounter rate and capture success can be more important than active predator choice in determining the prey that are consumed. Similarly, Juanes \& Conover (1994) suggested that size-selection patterns commonly observed among piscivorous fishes may not represent active behavioral choice by predators, but rather passive selection driven by size-related differences in prey encounter probability and susceptibility to capture. They hypothesize that piscivores may attack all prey within gape limitations that are encountered, with diet ultimately being determined by relative prey densities available and ease of capture. We agree with these hypotheses and conclude further that differences in prey morphology and behavior in the presence of predators may also affect which prey are attacked.

Experiments to evaluate selective feeding by piscivores are rarely observed directly or video recorded, thus quantification of relative attack proportions on different prey presented simultaneously is infrequent. However, when behavioral processes have been observed, differential prey behavior has been found to significantly affect the distribution of predator attacks and overall mortality of prey. Christensen \& Persson (1993) observed a greater number of attacks by piscivorous adult perch on juvenile perch compared to juvenile roach prey in vegetation and no structure treatments, and concluded that species-specific antipredator behavioral differences played an important role in predator selection. Utne-Palm (2000) found that attacks on 3 prey species by goby predators were directly related to differences in prey activity levels once detected by a predator. During our experiments, the majority of bluefish attacks were on solitary prey individuals that had become isolated from the school, which may be a common attack strategy of fish predators (Pitcher \& Parrish 1993). Our observations revealed that large bay anchovy tended to separate themselves from the school more frequently than smaller individuals, supporting the importance of behavioral prey differences to selective feeding processes. We conclude that differences in behavior of large and small bay anchovy in the presence of bluefish predators affected predator attack probabilities and the resulting patterns of selective feeding.

Our laboratory results demonstrating significant positive size selection by bluefish predators feeding on bay anchovy are not consistent with patterns of bluefish size selection observed in the field. In several earlier studies, we have shown bluefish to feed on smaller sizes of bay anchovy from those available in coastal waters (Juanes \& Conover 1995, Scharf et al. 1997, Buckel et al. 1999b). We also found that bluefish fed predominantly on bay anchovy of small relative size (20 to $30 \%$ of predator size), much smaller than the most profitable sizes predicted from laboratory experiments. However, our laboratory derived profitability curves do not account for differences in field density, and hence encounter rate, of bay anchovy of varying size. They serve as an index of predator foraging efficiency based on prey mass- and size-dependent functions of handling costs and capture success when all prey are readily available, and may not accurately predict the sizes of prey eaten by predators when encounter rates and search costs vary with prey size. In fact, large differences in encounter probability among prey may override other factors that contribute to determining predator feeding patterns. Bay anchovy undergo multiple spawning events during summer months in US east coast estuaries (Vouglitois et al. 1987, Newberger \& Houde 1995), producing high densities of small juveniles ( 20 to $30 \mathrm{~mm} \mathrm{TL}$ ) that are continuously available as forage. Juvenile bluefish are likely to encounter very high densities of small bay anchovy throughout sum- 
mer months in these systems, leading to their numerical dominance in bluefish diets. In addition, small bay anchovy are often not sampled efficiently with seines and trawls, which may bias length frequency distributions of available bay anchovy toward larger sizes and cause the negative size selection observed in the field to appear more dramatic.

Large body size in young fish can provide a refuge from gape-limited predators, with the number of potential predators usually declining as body size increases (Werner \& Gilliam 1984). Fast growth achieved during early ontogeny is generally thought to reduce mortality risks that are strongly associated with body size (Miller et al. 1988). In freshwater systems, the primary fish prey, such as sunfish Lepomis spp. and gizzard shad Dorosoma cepedianum, can reach size refuges that reduce their vulnerability to piscivores, often with significant effects on predator diets and growth rates (Olson 1996, Donovan et al. 1997, Michaletz 1997, Sutton \& Ney 2001). The high capture success on large relative prey sizes and strong positive size selection by bluefish predators observed in this study suggest that bay anchovy may never achieve a size refuge from predation. Although bluefish feed heavily on 20 to $40 \mathrm{~mm}$ TL bay anchovy, which are probably considerably more abundant than larger fish during summer, relatively large bay anchovy (>50 mm TL) are routinely recovered from their stomachs. When coupled with morphological measurements, behavioral experiments indicate that juvenile bluefish predators are capable of capturing and ingesting even the largest bay anchovy found in US east coast estuaries.

The lack of a size refuge from predation and their high susceptibility to an ever present suite of piscivores may represent distinct selective forces that have molded the life history of bay anchovy. The life history strategy of bay anchovy has been described as 'opportunistic', because they demonstrate a high intrinsic rate of population growth due to early maturation, batch spawning, fast growth rates of larvae, and rapid population replacement (Cowan et al. 1999, Rose et al. 1999). Cowan et al. (1999) conclude that this life history strategy is well suited to ensure cohort persistence in the face of heavy mortality based upon bay anchovy achieving growth to mortality ratios greater than 1 $(G: Z>1)$ at small body sizes. Their modeling results demonstrate that cohorts of bay anchovy begin to increase biomass at about 8 to $10 \mathrm{~mm}$ TL with peaks in G: $Z$ occurring in late larval to early juvenile stages ( 25 to $40 \mathrm{~mm}$ TL) (Cowan et al. 1999). Our findings suggest that bay anchovy cohorts may experience heavy predation mortality throughout their ontogeny, and reinforce the importance of predation as a force structuring bay anchovy population dynamics and life history.
Acknowledgements. We are especially grateful to the staff of the Behavioral Ecology Branch of the Northeast Fisheries Science Center for their hospitality and for providing laboratory space, tanks, equipment, boat time, and assistance with all aspects of this research. We also thank all of the summer interns who provided an abundance of help with these experiments, including Julia Brischler, Megan Haggerty, Stepanie Jaeger, Jackie Stent, and especially Patricia McGinn. We also appreciate the help of Don McMillan for his assistance with the location and collection of bay anchovy. Howard Browman, James Cowan, Thomas Miller, and several anonymous reviewers provided many constructive suggestions on earlier drafts. This work was supported by a research grant from the Hudson River Foundation for Environmental Science and Research (to F.J. and J.B.).

\section{LITERATURE CITED}

Baird D, Ulanowicz RE (1989) An energy flow network for the Chesapeake Bay. Ecol Monogr 59:329-364

Bigelow HB, Schroeder WC (1953) Fishes of the Gulf of Maine. Fish Bull (Wash, DC) 53:1-577

Breck JE (1993) Foraging theory and piscivorous fish: are forage fish just big zooplankton? Trans Am Fish Soc 122: 902-911

Buckel JA, Conover DO (1996) Gastric evacuation rates of piscivorous young-of-the-year bluefish. Trans Am Fish Soc 125:591-599

Buckel JA, Conover DO (1997) Movements, feeding chronology, and daily ration of piscivorous young-of-the-year bluefish (Pomatomus saltatrix) in the Hudson River estuary. Fish Bull 95:665-679

Buckel JA, McKown KA (in press) Competition between juvenile striped bass and bluefish: resource partitioning and growth rate. Mar Ecol Prog Ser

Buckel JA, Conover DO, Steinberg ND, McKown KA (1999a) Impact of age-0 bluefish (Pomatomus saltatrix) predation on age- 0 fishes in the Hudson River estuary: evidence for density-dependent loss of juvenile striped bass (Morone saxatilis). Can J Fish Aquat Sci 56:275-287

Buckel JA, Fogarty MJ, Conover DO (1999b) Foraging habits of bluefish, Pomatomus saltatrix, on the U.S. east coast continental shelf. Fish Bull 97:758-775

Cade BS, Terrell JW, Schroeder, RL (1999) Estimating effects of limiting factors with regression quantiles. Ecology 80: 311-323

Castro LR, Cowen RK (1991) Environmental factors affecting the early life history of bay anchovy Anchoa mitchilli in Great South Bay, New York. Mar Ecol Prog Ser 76: 235-247

Christensen B (1996) Predator foraging capabilities and prey antipredator behaviours: pre- versus postcapture constraints on size-dependent predator-prey interactions. Oikos 76:368-380

Christensen B, Persson L (1993) Species-specific antipredatory behaviours: effects on prey choice in different habitats. Behav Ecol Sociobiol 32:1-9

Cowan JH Jr, Houde ED (1992) Size-dependent predation on marine fish larvae by ctenophores, scyphomedusae, and planktivorous fish. Fish Oceanogr 1:113-126

Cowan JH Jr, Houde ED (1993) Relative predation potentials of scyphomedusae, ctenophores, and planktivorous fish on ichthyoplankton in Chesapeake Bay. Mar Ecol Prog Ser 95:55-65

Cowan JH Jr, Rose KA, Houde ED, Wang SB, Young J (1999) Modeling effects of increased larval mortality on bay 
anchovy population dynamics in the mesohaline Chesapeake Bay: evidence for compensatory reserve. Mar Ecol Prog Ser 185:133-146

Donovan NS, Stein RA, White MM (1997) Enhancing percid stocking success by understanding age-0 piscivore-prey interactions in reservoirs. Ecol Appl 7:1311-1329

Dorsey SE, Houde ED, Gamble JC (1996) Cohort abundances and daily variability in mortality of eggs and yolk-sac larvae of bay anchovy, Anchoa mitchilli, in Chesapeake Bay. Fish Bull 94:257-267

Einfalt LM, Wahl DH (1997) Prey selection by juvenile walleye as influenced by prey morphology and behavior. Can J Fish Aquat Sci 54:2618-2626

Ellis T, Gibson RN (1997) Predation of 0-group flatfishes by 0-group cod: handling times and size-selection. Mar Ecol Prog Ser 149:83-90

Friedland KD, Garman GC, Bejda AJ, Studholme AL, Olla B (1988) Interannual variation in diet and condition in juvenile bluefish during estuarine residency. Trans Am Fish Soc 117:474-479

Gardinier MN, Hoff TB (1982) Diet of striped bass in the Hudson River estuary. NY Fish Game J 29:152-165

Hart P, Hamrin SF (1988) Pike as a selective predator. Effects of prey size, availability, cover, and pike jaw dimensions. Oikos 51:220-226

Hart PJB, Hamrin SF (1990) The role of behaviour and morphology in the selection of prey by pike. In: Hughes RN (ed) Behavioural mechanisms of food selection. Springer Verlag, Berlin, p 235-253

Hartman KJ, Brandt SB (1995) Trophic resource partitioning, diets, and growth of sympatric estuarine predators. Trans Am Fish Soc 124:520-537

Hildebrand SF, Schroeder WC (1928) Fishes of Chesapeake Bay. Bulletin of the US Bureau of Fisheries, Vol 43, Part 1

Houde ED, Gamble JC, Dorsey SE, Cowan JH Jr (1994) Drifting mesocosms: the influence of gelatinous zooplankton on mortality of bay anchovy, Anchoa mitchilli, eggs and yolk-sac larvae. ICES J Mar Sci 51:383-394

Juanes $F$ (1994) What determines prey size selectivity in piscivorous fishes? In: Stouder DJ, Fresh KL, Feller RJ (eds) Theory and application in fish feeding ecology. South Carolina University Press, Columbia, p 79-100

Juanes F, Conover DO (1994) Piscivory and prey size selection in young-of-the-year bluefish: Predator preference or sizedependent capture success? Mar Ecol Prog Ser 114:59-69

Juanes F, Conover DO (1995) Size-structured piscivory: advection and the linkage between predator and prey recruitment in young-of-the-year bluefish. Mar Ecol Prog Ser 128:287-304

Juanes F, Marks RE, McKown KA, Conover DO (1993) Predation by age-0 bluefish on age-0 anadromous fishes in the Hudson River Estuary. Trans Am Fish Soc 122:348-356

Leak JC, Houde ED (1987) Cohort growth and survival of bay anchovy Anchoa mitchilli larvae in Biscayne Bay, Florida. Mar Ecol Prog Ser 37:109-122

Lundvall D, Svanbäck R, Persson L, Byström P (1999) Sizedependent predation in piscivores: Interactions between predator foraging and prey avoidance abilities. Can J Fish Aquat Sci 56:1285-1292

Luo JL, Brandt SB (1993) Bay anchovy Anchoa mitchilli production and consumption in mid-Chesapeake Bay based on a bioenergetics model and acoustic measures of fish abundance. Mar Ecol Prog Ser 98:223-236

Luo J, Musick JA (1991) Reproductive biology of the bay anchovy in Chesapeake Bay. Trans Am Fish Soc 120: 701-710

Manderson JP, Phelan BA, Bejda AJ, Stehlik LL, Stoner AW
(1999) Predation by striped searobin (Prionotus evolans, Triglidae) on young-of-the-year winter flounder (Pseudopleuronectes americanus, Walbaum): Examining prey size selection and prey choice using field observations and laboratory experiments. J Exp Mar Biol Ecol 242:211-231

Manooch CS (1973) Food habits of yearling and adult striped bass, Morone saxatilis (Walbaum), from Albemarle Sound, North Carolina. Chesapeake Sci 14:73-86

Merriner JV (1975) Food habits of the weakfish, Cynoscion regalis, in North Carolina waters. Chesapeake Sci 16: $74-76$

Michaletz PH (1997) Influence of abundance and size of age0 gizzard shad on predator diets, diet overlap, and growth. Trans Am Fish Soc 126:101-111

Miller TJ, Crowder LB, Rice JA, Marschall EA (1988) Larval size and recruitment mechanisms in fishes: toward a conceptual framework. Can J Fish Aquat Sci 45:1657-1670

Newberger TA, Houde ED (1995) Population biology of bay anchovy Anchoa mitchilli in the mid Chesapeake Bay. Mar Ecol Prog Ser 116:25-37

Nilsson PA, Brönmark C (2000) Prey vulnerability to a gapesize limited predator: behavioural and morphological impacts on northern pike piscivory. Oikos 88:539-546

Olson MH (1996) Ontogenetic niche shifts in largemouth bass: vulnerability and consequences for first-year growth. Ecology 77:179-190

Pitcher TJ, Parrish JK (1993) Functions of shoaling behaviour in teleosts. In: Pitcher TJ (ed) Behaviour of teleost fishes. Chapman and Hall, London, p 363-440

Poole JC (1964) Feeding habits of summer flounder in Great South Bay. NY Fish Game J 11:28-34

Purcell JE, Nemazie DA, Dorsey SE, Houde ED, Gamble JC (1994) Predation mortality of bay anchovy Anchoa mitchilli eggs and larvae due to scyphomedusae and ctenophores in Chesapeake Bay. Mar Ecol Prog Ser 114:47-58

Rice JA, Crowder LB, Rose KA (1993) Interactions between sizestructured predator and prey populations: experimental test and model comparison. Trans Am Fish Soc 122:481-491

Rilling GC, Houde ED (1999) Regional and temporal variability in growth and mortality of bay anchovy, Anchoa mitchilli, larvae in Chesapeake Bay. Fish Bull 97:555-563

Rose KA, Cowan JH Jr, Clarke ME, Houde ED, Wang SB (1999) An individual-based model of bay anchovy population dynamics in the mesohaline region of Chesapeake Bay. Mar Ecol Prog Ser 185:113-132

Schaefer RH (1970) Feeding habits of striped bass, Morone saxatilis, from the surf waters of Long Island. NY Fish Game J 17:1-17

Scharf FS, Buckel JA, Juanes F, Conover DO (1997) Estimating piscine prey size from partial remains: testing for shifts in foraging mode by juvenile bluefish. Environ Biol Fish 49:377-388

Scharf FS, Buckel JA, Juanes F, Conover DO (1998b) Predation by juvenile piscivorous bluefish (Pomatomus saltatrix): the influence of prey to predator size ratio and prey type on predator capture success and prey profitability. Can J Fish Aquat Sci 55:1695-1703

Scharf FS, Juanes F, Sutherland M (1998a) Inferring ecological relationships from the edges of scatter diagrams: comparison of regression techniques. Ecology 79:448-460

Sih A, Christensen B (2001) Optimal diet theory: when does it work, and when and why does it fail? Anim Behav 61: 379-390

Sih A, Moore RD (1990) Interacting effects of predator and prey behavior in determining diets. In: Hughes RN (ed) Behavioural mechanisms of food selection. Springer Verlag, Berlin, p 771-796 
Sutton T, Ney J (2001) Size-dependent mechanisms influencing first-year growth and winter survival of stocked striped bass in a Virginia mainstream reservoir. Trans Am Fish Soc 130:1-17

Utne-Palm AC (2000) Prey visibility, activity, size and catchability's (evasiveness) influence on Gobiusculus flavescens prey choice. Sarsia 85:157-165

Vouglitois JJ, Able KW, Kurtz RJ, Tighe KA (1987) Life history and population dynamics of the bay anchovy in New Jersey. Trans Am Fish Soc 116:141-153

Editorial responsibility: Howard Browman (Contributing Editor), Storebø, Norway
Wang SB, Houde ED (1995) Distribution, relative abundance, biomass and production of bay anchovy Anchoa mitchilli in the Chesapeake Bay. Mar Ecol Prog Ser 121:27-38

Werner EE, Gilliam JF (1984) The ontogenetic niche and species interactions in size-structured populations. Annu Rev Ecol Sys 15:393-426

Zastrow CE, Houde ED, Morin LG (1991) Spawning, fecundity, hatch-date frequency and young-of-the-year growth of bay anchovy Anchoa mitchilli in mid-Chesapeake Bay. Mar Ecol Prog Ser 73:161-171

Submitted: August 15, 2001; Accepted: November 19, 2001 Proofs received from author(s): April 18, 2002 